\title{
The Economics of Arundo donax-A Systematic Literature Review
}

\author{
Attila Jámbor * and Áron Török \\ Department of Agricultural Economics and Rural Development, Corvinus University of Budapest, Budapest, \\ 1093 Hungary, Hungary \\ * Correspondence: attila.jambor@uni-corvinus.hu
}

Received: 14 June 2019; Accepted: 1 August 2019; Published: 5 August 2019

\begin{abstract}
Arundo donax (giant reed) is an herbaceous, perennial and non-food crop producing dry biomass with relatively high yields in many regions and under different climates. Although there exists a large amount of literature on A. donax, the economic aspects are somehow neglected or are very much limited in most papers. Therefore, the aim of this paper is to analyse the economics of A. donax by applying a systematic literature review of the field. Our sample consists of 68 relevant studies out of the 6009 identified, classified into four groups: Bioenergy, agronomy, invasiveness and phytoremediation. Most papers were focusing on Italy and on the Mediterranean region and were written on the bioenergy aspect. Most studies suggest that $A$. donax has a relatively high energy balance and yields, high investment but low maintenance costs and high potentials for phytoremediation of contaminated soils. However, a certain section of the literature, mainly based on US experience, shows that giant reed should be produced with care due to its invasiveness hazard. On the whole, A. donax was found to have high economic potentials for biomass production in marginal as well as disadvantageous lands operated by small farmers in the Mediterranean region.
\end{abstract}

Keywords: Arundo donax; economics; review

\section{Introduction}

Arundo donax L. (common name giant reed or giant cane) is an herbaceous, rhizomatous perennial and non-food crop producing dry biomass with relatively high yields with lower agronomic inputs requirement compared to the traditional (bioenergy) crops. The plant is propagated mostly by in vitro or hydroponic methods [1]. Although it has Asian origins, the species is now globally dispersed and is cultivated in many regions and under different climates. The plant tolerates diverse ecological and soil conditions and is resistant to most pests, which makes its production attractive [2]. Giant reed has no viable seeds and therefore can be considered as a sterile plant, however the risk of invasiveness in flooded areas can be high [3]. In general, $A$. donax has great biomass potential requiring lower input level while a wide range of climatic conditions and soil types (even polluted) is suitable for its production.

Although there exists a large amount of literature on A. donax, the economic aspects are somehow neglected or are very much limited in most papers. Several literature reviews including of giant reed also exist. However, they are mostly focusing on the technical aspects of $A$. donax cultivation, inter alia bioenergy production techniques [4], grassland management [5], combusting methods [6] or landfill sites revegetation and phytoremediation.

Therefore, the aim of this paper is to analyse the economics of $A$. donax by applying a systematic literature review of the field. In doing so, the paper contributes to the existing literature by concentrating on the economic aspects of $A$. donax production. Where and how to produce this plant to be profitable? How profitable it is compared to other plants? What is its potential uses and how much are they 
worth? What topics the economics literature identify when talking about $A$. donax? These are the main questions to be answered by our review.

The paper is structured as follows: The second chapter demonstrates how our sample was constructed together with its basic descriptive statistics, the third chapter shows our results by different categories and the fourth chapter concludes.

\section{Materials and Methods}

In order to achieve a comprehensive overview of the economics of $A$. donax, a wide online literature search was conducted using five electronic databases: Web of Science, Scopus, JSTOR, Science Direct and ProQuest. The combination of the keywords "Arundo* donax" and "Giant* reed". These search terms had to appear in the title, in the abstract, or in the keywords of the sources. The search was restricted to articles published in English.

The initial search obtained 6009 entries across all databases. After removing duplicates, 3582 studies were identified as an initial dataset of studies. The next screening criteria was to include only papers with "economy" in the title, in the abstract or in the keywords. After this second step of screening, only 280 studies were selected. This indicates well that a wide set of literature for A. donax exists. However, the number of studies focusing on the economics of giant reed is quite limited.

To ensure that only relevant articles were included in the final analysis and to eliminate duplicates, the online software package Covidence was used. The screening and identification process are illustrated in Figure 1. Once duplicates had been removed, all articles were screened for relevance to the study. Initially this screening was independent, but then the authors met to discuss articles where there were different screening outcomes. This initial screening led to 179 articles being excluded. The remaining 101 articles were also each screened by both authors. Again, the initial screening was independent, but this was followed by discussion of the merits of each study. Additional criteria for exclusion were that the article was not available as a full text, and others turned out not to be focusing on the economic aspects. The final set of relevant articles with was 68 publications from the systematic literature review.

In Figure 2 the topics of the identified articles are presented. Obviously, a paper can focus on more than one of the defined topics (bioenergy, agronomy, invasiveness and phytoremediation/waste management). The numbers clearly show that research on the economics of $A$. donax is very much about the bioenergy aspects, every second paper highlighted this topic.

Studies focusing on Italy play the most important role, as more than $40 \%$ of the papers was related to this Mediterranean country. Besides research with a global view, the USA and other South-European (mainly Greece and Spain) studies were dominating the giant reed related studies. (Figure 3)

It is interesting to mention that $38 \%$ of the papers were following a theoretic approach and less than a third of the studies were purely empirical. The share of literature reviews was higher than papers with mixed (both theoretical and empirical) methodology (Figure 4). 


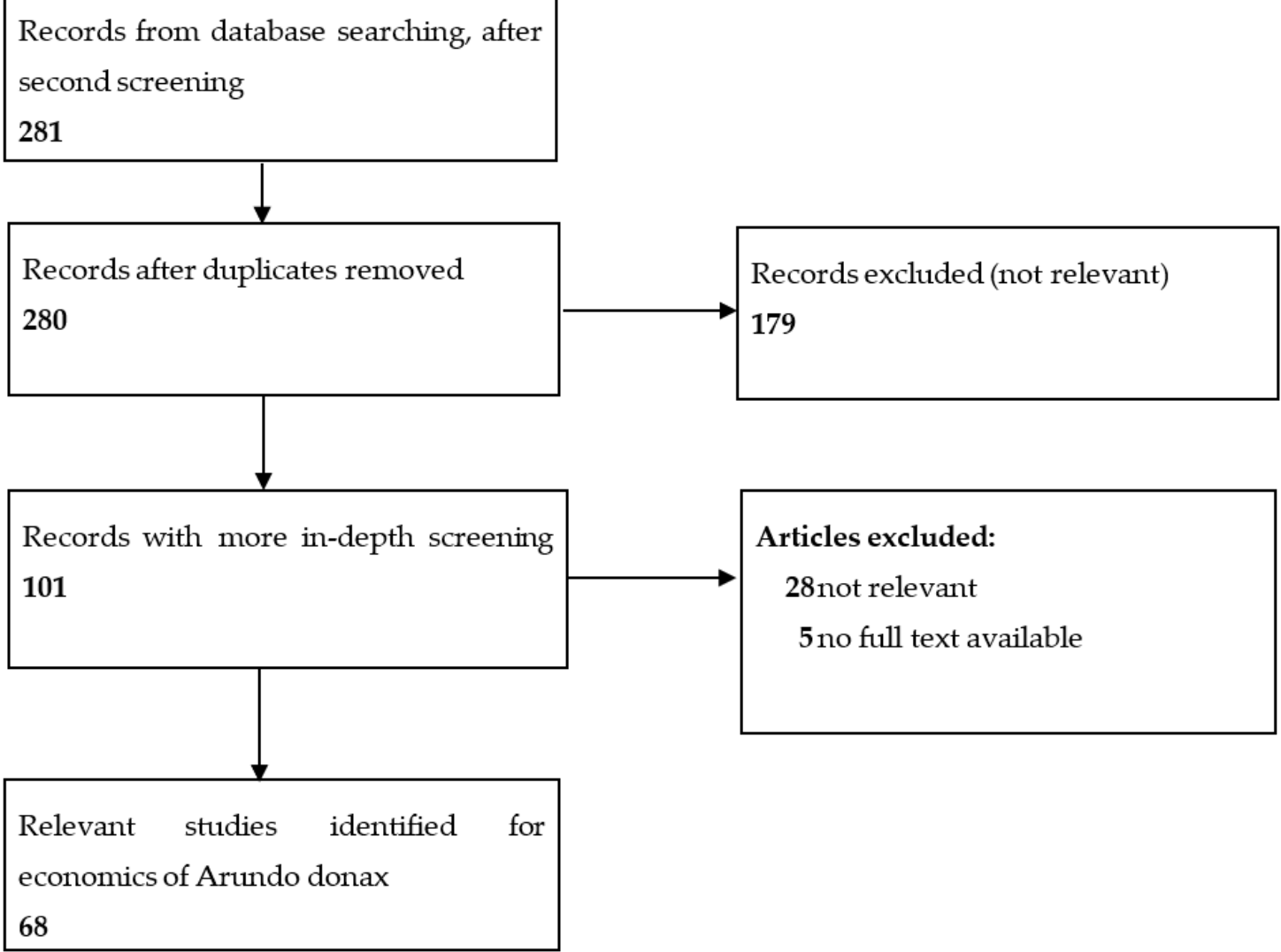

Figure 1. Process used to identify studies of the economics of Arundo donax. Source: Own composition.

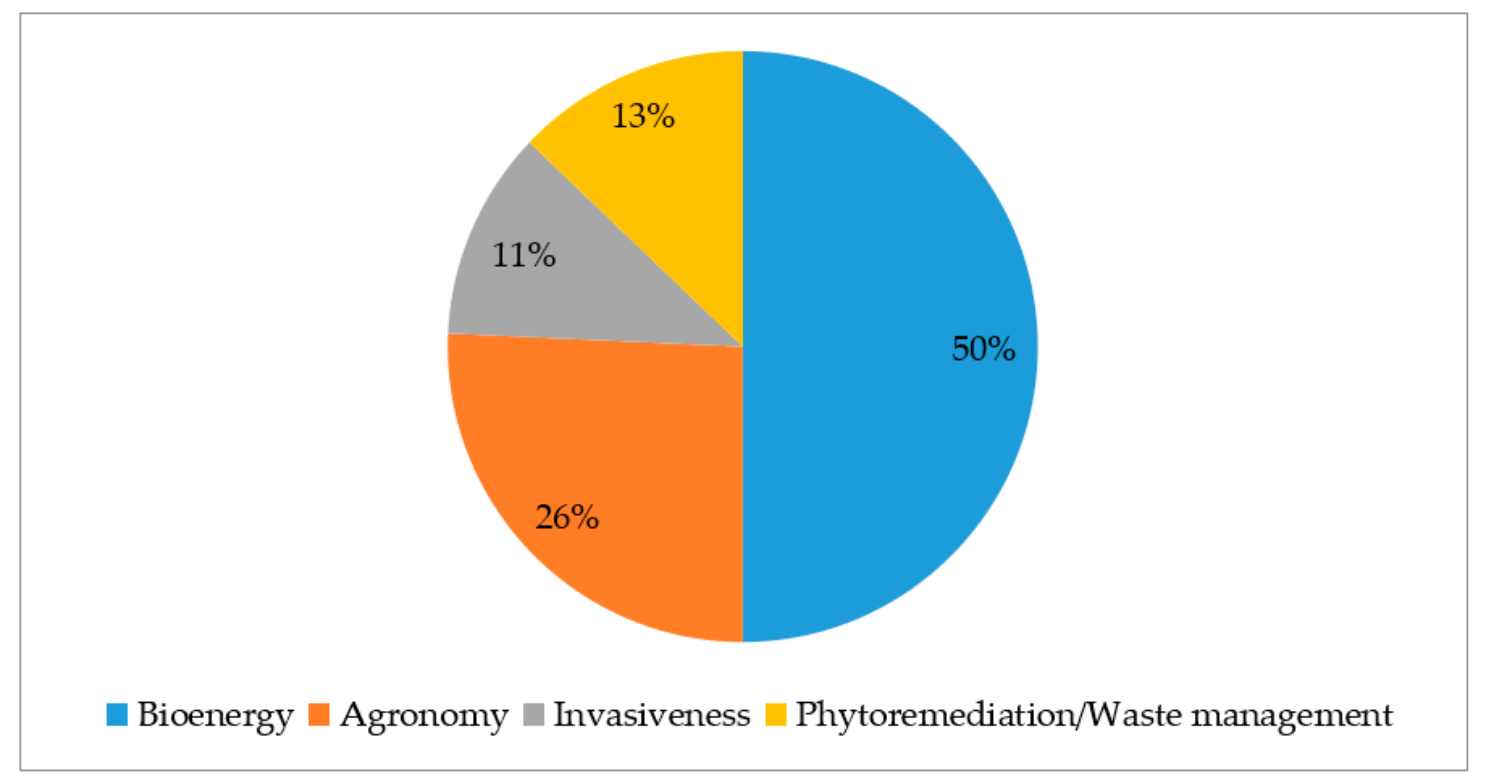

Figure 2. Topics among the 68 identified studies. Source: Own composition. 


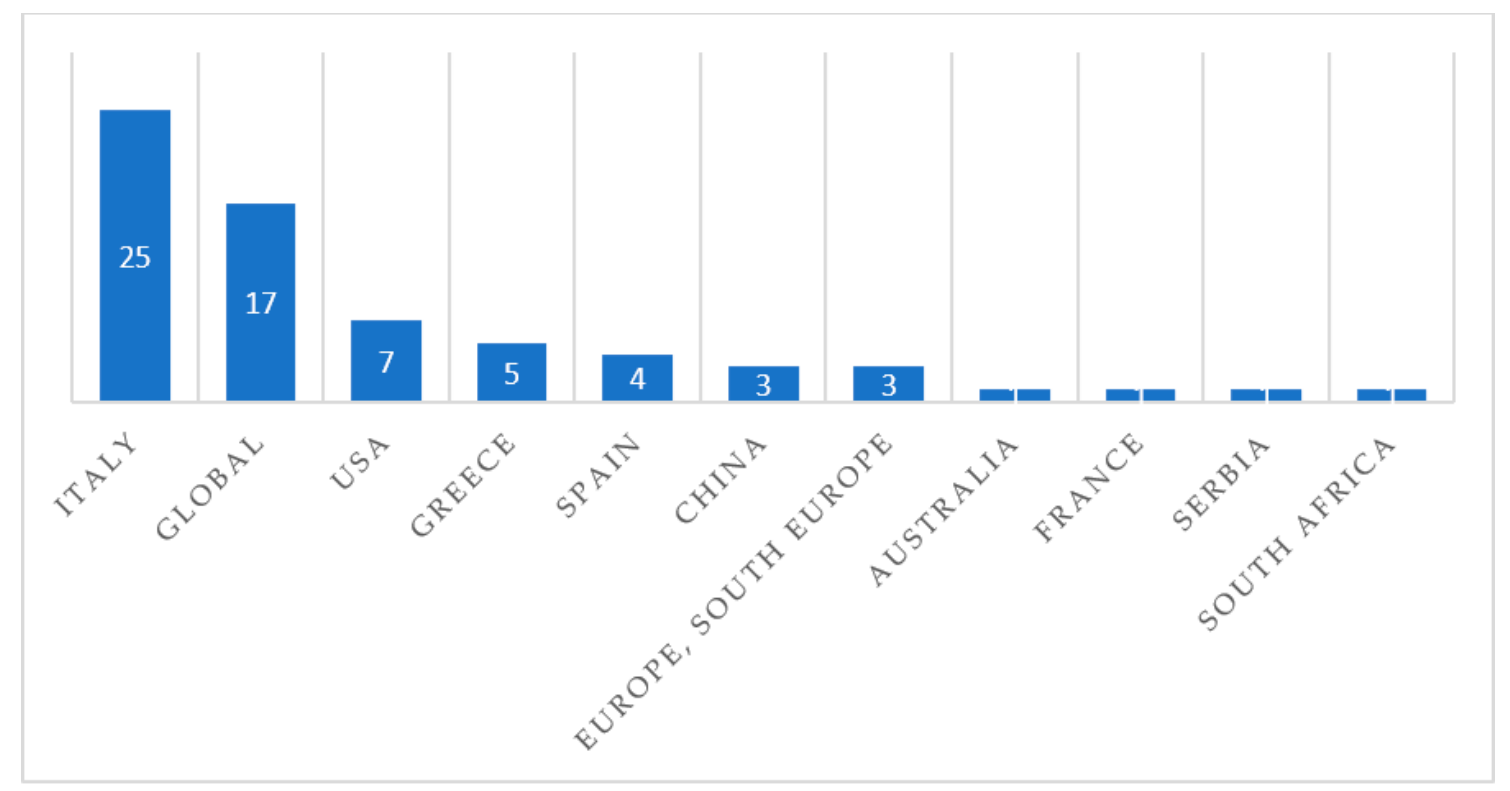

Figure 3. Territorial focus of 68 selected papers. Source: Own composition.

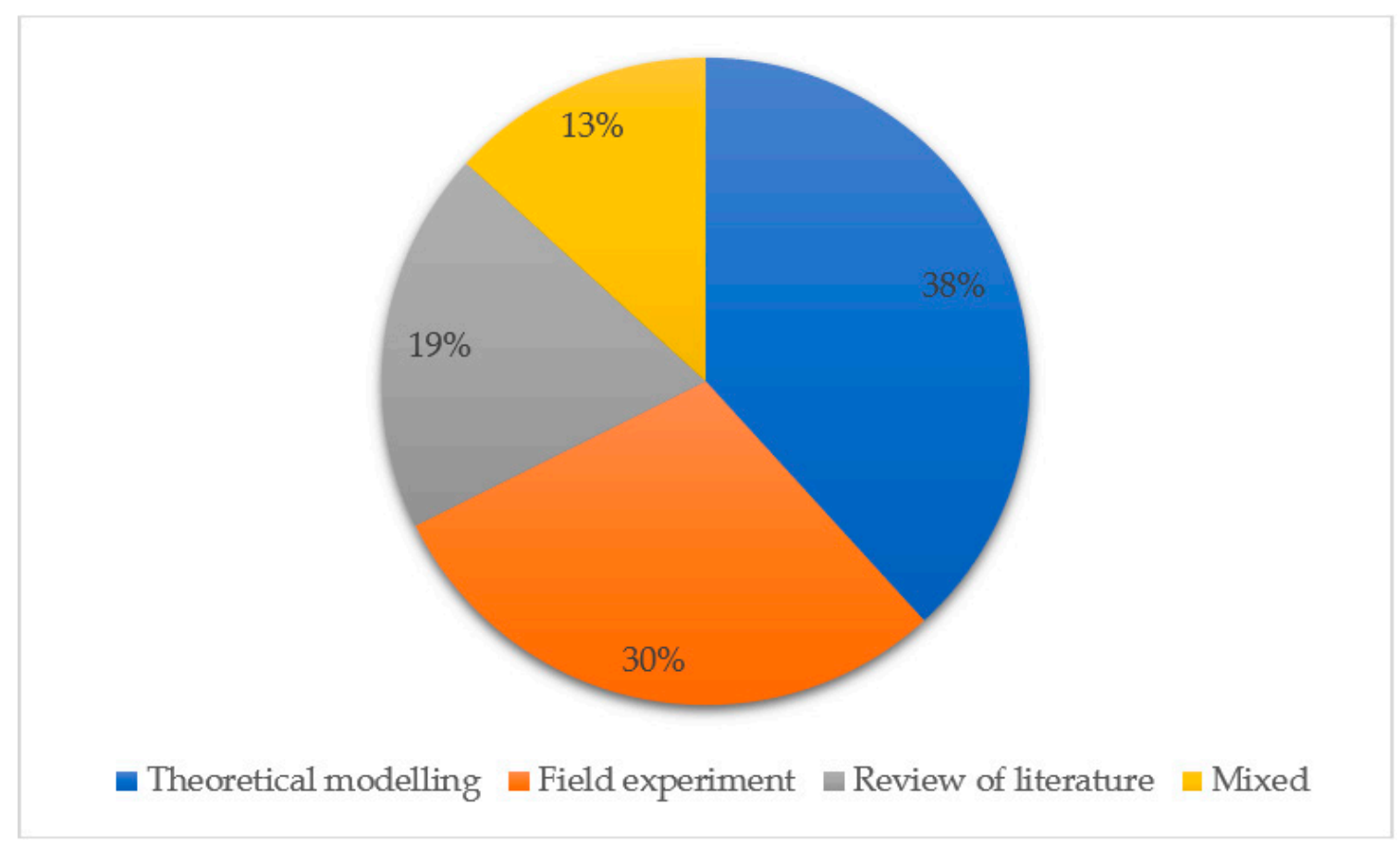

Figure 4. Methodologies used in the 68 selected papers. Source: Own composition.

\section{Results}

This section may be divided by subheadings. It should provide a concise and precise description of the experimental results, their interpretation as well as the experimental conclusions that can be drawn.

\subsection{Bioenergy from Perennial Crops}

The majority of the studies identified in our systematic literature review had a focus on bioenergy. The biological raw materials (biomass) gained from giant reed cultivation can be utilized mainly for three types of bioenergy: Bioethanol, bio-methane and solid biofuels (for combustion purposes, in briquetted and pelleted forms). 


\subsubsection{Biomass Production-Global Studies}

Many studies with a global outlook (mostly several literature reviews) identified giant reed as one of the most promising candidates for biomass production (see Table 1). In a European context, the energy balances of the use of herbaceous lignocellulosics as raw fibre biomass production was in the focus of Venturi and Venturi [7]. Among crops produced in European agricultural systems, in the category of perennial crops, A. donax had the best characteristics. However, Miscanthus giganteus must also be taken into consideration. Giant reed, as a perennial energy crop for biofuel production, is widely used in the United States in high quantity, together with switch grass, Miscanthus, canary grass and alfalfa [8]. Permanent grasslands as venues of producing biomass for combusting purposes were highlighted in the review of Prochnow, Heiermann, Plöchl, Amon and Hobbs [6]. According to the studies they investigated, giant reed is among the most promising grass species. In terms of sustainability, extensive grassland management and a low level of mineral fertilization is required and using conventional farm machinery contributes to the best economic performances. For combusting purposes, pelletizing or briquetting might also be required.

Table 1. Summary of studies on biomass potential of Arundo donax (global outlook).

\begin{tabular}{|c|c|c|c|c|}
\hline Study & Topic & Country & Method & Results \\
\hline $\begin{array}{l}\text { Prochnow et al. } \\
\qquad(2009)\end{array}$ & $\begin{array}{l}\text { Permanent grasslands } \\
\text { as venue of producing } \\
\text { biomass for } \\
\text { combusting purposes }\end{array}$ & Global & Review of literature & $\begin{array}{l}\text { 1. Giant reed is among the } \\
\text { most promising grass species } \\
\text { 2. For sustainable production } \\
\text { extensive management, low } \\
\text { level of inputs and using } \\
\text { conventional machineries } \\
\text { are required }\end{array}$ \\
\hline $\begin{array}{l}\text { Nackley et al. } \\
\text { (2015) }\end{array}$ & $\begin{array}{l}\text { Bioenergy production } \\
\text { from invasive species }\end{array}$ & Global & Review of literature & $\begin{array}{l}\text { 1. Miscanthus giganteus and } \\
\text { Arundo donax are the most } \\
\text { promising biomass crop } \\
\text { 2. Giant reed can be } \\
\text { considered sustainable in } \\
\text { terms of economics and social } \\
\text { development, however } \\
\text { because of the invasiveness } \\
\text { the environmental aspects } \\
\text { should considered }\end{array}$ \\
\hline
\end{tabular}


Others narrow the candidates to two potential crops: M. giganteus and A. donax as the most ideal bioenergy crops. However, the latter is often criticized because of its invasive characteristics. Giant reed is considered to be sustainable in terms of economics (biomass supply and revenue generating) and social development (neutral or negative $\mathrm{CO}_{2}$ emissions and avoiding food-crop competition), however in terms of environmental protection it has deficiencies, mainly in reducing freshwater resources and having negative biodiversity impacts [9].

From a purely economic aspect, investing in perennial plants for biomass production purposes consists of high establishment costs that are paid only in the first year but after the initial years the maintenance cost of the plants reduces only for basic fertilisation in every 3-4 years. On the other hand, revenues can be expected only from the second or third year, while the average life cycle of such plants can be 15-20 years [10]. Using the life cycle costing methodology it was found that the cost per dry tonne of giant reed (65 EUR) is lower than the cost of Miscanthus and switchgrass (both 65-80 EUR); fertilisation, irrigation, harvesting and transport are the dominant cost items in all three crops. The cost of establishment is much higher for giant reed and Miscanthus, because in these cases rhizomes are required with expensive plantation. It was also found that using marginal lands reduces the yields and therefore from an economical point-of-view makes it less attractive for a farmer.

\subsubsection{Biomass Production-Country and Crop Specific Studies}

Biomass potential of giant reed is a key aspect of related research (see Table 2). An early study of Alderucci, et al. [11] has identified giant reed as one of the most promising biomass plant for Sicily, Italy. The estimation expected to contribute $20 \%$ of the island's total energy requirement which giant reed could be a part of, together with other candidates, also including nitrogen-fixing trees. The Sicilian biomass potential was also analysed by Chinnici, et al. [12] and they found that after livestock sewage, dedicated bioenergy crops represent the second highest amount of biomass potential. Among the perennials giant reed can offer a valid alternative to arable farming, especially on marginal lands. However, the low processing capacities make bioenergy potential underexploited.

In a study from the Balkans, switch grass, red canary grass, giant reed and Miscanthus were identified as the most promising perennial biomass inputs. Plant experiments in Serbia proved for Miscanthus to be an efficient solution under country-specific conditions and this could also apply for the other multi-seasonal species [13].

The USA is also committed for bioenergy production from lignocellulosic feedstocks, and switchgrass together with giant reed are both considered as ideal input candidates as they find ideal conditions for growth in warm climates in the south-eastern US states with sufficient water availability, and they are both tolerant for the extreme natural conditions provided by the marginal lands available for biomass production. However, the aspect of invasiveness also has to be considered. Therefore, even if giant reed allures with higher yield, a better social acceptance helps switchgrass to be produced more. The DAYCENT model, using long-term field research results as parameters, also confirmed the higher yields for giant reed compared to switchgrass (16.3 t/ha vs. $7.9 \mathrm{t} / \mathrm{ha})$, however fluctuation was also higher [3]. Field research in three different locations in Florida, USA, showed that in terms of dry biomass yield, giant reed was exceeded by sugarcane, sweetcane, energycane and elephant grass, indicating that biomass plants requiring specific conditions might overpass $A$. donax [14].

In Greece, cardoon and giant reed was compared to evaluate their energy crop performances as input for biomass district heating. Both plants are expected to have 15 years of economic life, and in their calculations they found that the total annual equivalent cost of giant reed is almost $60 \%$ higher (1180 vs. 744 EUR/ha), mainly due to the higher establishment costs. Concerning profitability, cardoon also performed better in all the scenarios. However, both can be economically feasible compared to conventional crop production under local circumstances if they are carefully integrated into the current production system (in terms of employment, equipment and timing) and—obviously—taking into consideration the several subsidies available for energy crop production in the EU [15]. 
Producing biomass on disadvantageous areas is a key aspect of the economics of giant reed. A comprehensive study focusing on the sustainability aspects of energy crops also synthetized the results of several EU-funded projects and stressed that switchgrass, Miscanthus, cardoon and giant reed are the most promising candidates to produce biomass in less favoured and marginal agricultural areas of Europe [16]. In terms of impacts on profitability they found that despite the promising profitability expectations, incentives (e.g., subsidies, tax credits and exemptions, and long-term pricing schemes) are required in order to gain the farmers' willingness to grow dedicated energy crops in the Mediterranean countries. Chiaramonti, et al. [17] found that sorghum and giant reed demonstrated the best growth rate on coastal and arid areas of the Mediterranean region. Pulighe, et al. [18] highlighted the biomass producing potential of several perennial species (including giant reed) on marginal and contaminated territory in Italy. They found that beside native perennial grass species, giant reed had very good comparative performances in terms of yield, irrigation needs, water-use efficiency and fertilizer use, even under less favourable agronomic circumstances. However, Sulas, et al. [19] found that under rainfed Mediterranean conditions, other native breeds like smilo grass can also achieve a high biomass output level and similar calorific value like giant reed.

Miscanthus, A. donax and switchgrass are in the focus of the study of Rodias, et al. [20] from an energy-balance point-of-view. A common framework, including all the in-field and transport operations was used in order to gain accurate and comparable results for all the crops. The results indicated that even though giant reed required the highest energy input, the energy balance (considering a 10-year-long period) was also the highest for Arundo (4654.4 GJ/ha), more than double the results of switchgrass (1760.3 GJ/ha) and significantly higher than Miscanthus (3025.3 GJ/ha). This also suggests that from the energetic balance point-of-view, giant reed is the most beneficial crop from the three selected. Several other studies [21,22] focussed on the best practices of giant reed cultivation, especially on harvesting methods in order to get the best feedstock for biomass energy production. As transportation has a great influence on the profitability of this value chain, the harvesting and storage methods have to be adjusted for the benefit of logistics. Field research proved that, in view of the whole chain economic cost, the two passes system of baling is more favourable than the single pass system (chipping and loading) and the two passes system of chipping and loading.

Using pre-treated sewage effluent for irrigation was in the focus of the study of Tzanakakis, et al. [23]. In a three-year-long field trial, they compared giant reed with other non-grass biomass candidates (Acacia cyanophylla, Eucalyptus camaldulensis and Populus nigra). They found that A. donax had the second highest energy production cost (2.34 EUR/GJ) but the highest nutrient-use efficiency for nitrogen and phosphorus. This makes giant reed a potential candidate to converse wastewater into bioenergy production. A similar approach was implemented by Zema, et al. [24], investigating the effects of using effluents of an urban wastewater depuration plant for biomass production with three energy crops (Typha latifolia, A. donax and Phragmites australis). Based on the two-year-long field research they found increased biomass yield and the highest energy yield per unit was measured for A. donax. Seshadri, et al. [25] also investigated the opportunities of using landfills for biomass production. According to the results, among the potential landfill biomass plants (sunflower, sugarcane, giant reed, willow, switch and Miscanthus) giant reed was undoubtedly the most promising breed with the highest biomass yield $(70.8 \mathrm{t} / \mathrm{ha})$. 
Table 2. Summary of studies on country- and crop-specific studies of Arundo donax biomass potential.

\begin{tabular}{|c|c|c|c|c|}
\hline Study & Topic & Country & Method & Results \\
\hline $\begin{array}{c}\text { Alderucci et al. } \\
\qquad(1993)\end{array}$ & $\begin{array}{l}\text { Energy supply } \\
\text { from biomass in } \\
\text { Sicily }\end{array}$ & Italy & $\begin{array}{l}\text { Theoretical } \\
\text { modelling }\end{array}$ & $\begin{array}{l}\text { Arundo donax is an important } \\
\text { biomass plant of Sicily, } \\
\text { together with other plants can } \\
\text { contribute up to } 20 \% \text { of energy } \\
\text { supply }\end{array}$ \\
\hline $\begin{array}{l}\text { Chinnici et al. } \\
\text { (2015) }\end{array}$ & $\begin{array}{l}\text { Availability of } \\
\text { biomass to produce } \\
\text { thermal or } \\
\text { Bio-methane } \\
\text { electricity }\end{array}$ & Italy & $\begin{array}{l}\text { Theoretical } \\
\text { modelling }\end{array}$ & $\begin{array}{l}\text { 1. After livestock sewage, } \\
\text { dedicated bioenergy crops } \\
\text { represent the second highest } \\
\text { amount of biomass potential } \\
\text { in Sicily } \\
\text { 2. Among the perennials giant } \\
\text { reed can offer a valid } \\
\text { alternative to arable farming, } \\
\text { especially on marginal lands }\end{array}$ \\
\hline $\begin{array}{l}\text { Milovanovic et al. } \\
\qquad(2012)\end{array}$ & $\begin{array}{c}\text { Biomass } \\
\text { production }\end{array}$ & Serbia & $\begin{array}{c}\text { Field } \\
\text { experiment }\end{array}$ & $\begin{array}{l}\text { 1. In Serbia, Miscanthus } \\
\text { proved to be the best solution } \\
\text { for biomass production } \\
\text { 2. Country specific conditions } \\
\text { require different } \\
\text { multi-seasonal species }\end{array}$ \\
\hline $\begin{array}{l}\text { Nocentini et al. } \\
\qquad(2018)\end{array}$ & $\begin{array}{l}\text { Switchgrass vs. } \\
\text { giant reed } \\
\text { comparison }\end{array}$ & USA & $\begin{array}{l}\text { Theoretical } \\
\text { modelling }\end{array}$ & $\begin{array}{l}\text { 1. Switchgrass together with } \\
\text { giant reed are both considered } \\
\text { as ideal input candidates for } \\
\text { biomass production } \\
\text { 2. Even though giant reed } \\
\text { allures with higher yield, the } \\
\text { better social acceptance helps } \\
\text { switchgrass to be produced } \\
\text { more }\end{array}$ \\
\hline $\begin{array}{l}\text { Singh et al. } \\
\text { (2015) }\end{array}$ & $\begin{array}{l}\text { Giant reed vs. } \\
\text { sugarcane, } \\
\text { sweetcane, } \\
\text { energycane and } \\
\text { elephant grass }\end{array}$ & USA & $\begin{array}{c}\text { Field } \\
\text { experiment }\end{array}$ & $\begin{array}{l}\text { In terms of dry biomass yield, } \\
\text { several plants can exceed giant } \\
\text { reed under specific conditions }\end{array}$ \\
\hline $\begin{array}{l}\text { Panoutsou } \\
\text { (2007) }\end{array}$ & $\begin{array}{l}\text { Cardoon vs. giant } \\
\text { reed comparison }\end{array}$ & Greece & Mixed & $\begin{array}{l}\text { 1. The total annual equivalent } \\
\text { cost of giant reed is almost } \\
60 \% \text { higher than cardoon } \\
\text { 2. Cardoon also resulted in } \\
\text { higher profitability ratio } \\
\text { 3. Both plants can be } \\
\text { economically feasible } \\
\text { compared to conventional } \\
\text { crop production if they are } \\
\text { well integrated }\end{array}$ \\
\hline $\begin{array}{l}\text { Pulighe et al. } \\
\qquad(2019)\end{array}$ & $\begin{array}{l}\text { Sustainability } \\
\text { aspects of energy } \\
\text { crops }\end{array}$ & Italy & $\begin{array}{l}\text { Review of } \\
\text { literature }\end{array}$ & $\begin{array}{l}\text { 1. Switchgrass, Miscanthus, } \\
\text { cardoon and giant reed are the } \\
\text { most promising candidates to } \\
\text { produce biomass in less } \\
\text { favoured and marginal } \\
\text { agricultural areas of Europe } \\
\text { 2. Incentives are required in } \\
\text { order to gain the farmers' } \\
\text { willingness to grow }\end{array}$ \\
\hline $\begin{array}{l}\text { Chiaramonti et al. } \\
\qquad(2000)\end{array}$ & $\begin{array}{c}\text { Rescuing } \\
\text { desalinated areas } \\
\text { by bioenergy and } \\
\text { crops }\end{array}$ & Spain & $\begin{array}{c}\text { Field } \\
\text { experiment }\end{array}$ & $\begin{array}{l}\text { Sorghum and giant reed } \\
\text { demonstrated the best growth } \\
\text { rate on coastal and arid area of } \\
\text { the Mediterranean region }\end{array}$ \\
\hline
\end{tabular}


Table 2. Cont.

\begin{tabular}{|c|c|c|c|c|}
\hline Study & Topic & Country & Method & Results \\
\hline $\begin{array}{l}\text { Pulighe et al. } \\
\text { (2016) }\end{array}$ & $\begin{array}{l}\text { Biomass } \\
\text { production on } \\
\text { marginal and } \\
\text { contaminated areas }\end{array}$ & Italy & Mixed & $\begin{array}{l}\text { Beside native perennial grass } \\
\text { species, giant reed had very } \\
\text { good comparative } \\
\text { performances in terms of yield, } \\
\text { irrigation needs, water-use } \\
\text { efficiency and fertilizer use }\end{array}$ \\
\hline $\begin{array}{l}\text { Sulas et al. } \\
\text { (2015) }\end{array}$ & $\begin{array}{l}\text { Perennial grasses } \\
\text { for bioenergy } \\
\text { production }\end{array}$ & Italy & $\begin{array}{c}\text { Field } \\
\text { experiment }\end{array}$ & $\begin{array}{l}\text { Under rainfed Mediterranean } \\
\text { conditions native breeds can } \\
\text { also achieve the high biomass } \\
\text { output level of Arundo donax }\end{array}$ \\
\hline $\begin{array}{l}\text { Rodias et al. } \\
\qquad(2017)\end{array}$ & $\begin{array}{l}\text { Energy balance of } \\
\text { Miscanthus, Arundo } \\
\text { donax and } \\
\text { switchgrass } \\
\text { production }\end{array}$ & Italy & Mixed & $\begin{array}{l}\text { Giant reed required the } \\
\text { highest energy input, but the } \\
\text { energy balance was also the } \\
\text { highest }\end{array}$ \\
\hline $\begin{array}{l}\text { Pari et al. } \\
\text { (2015) }\end{array}$ & $\begin{array}{c}\text { Arundo donax } \\
\text { harvesting systems }\end{array}$ & Italy, Spain & $\begin{array}{c}\text { Field } \\
\text { experiment }\end{array}$ & $\begin{array}{l}\text { In case of Arundo donax, two } \\
\text { passes system of baling is } \\
\text { more favourable than single } \\
\text { pass system (chipping and } \\
\text { loading) and two passes } \\
\text { system of chipping and } \\
\text { loading }\end{array}$ \\
\hline $\begin{array}{l}\text { Pari et al. } \\
\quad(2016)\end{array}$ & $\begin{array}{l}\text { Arundo donax } \\
\text { logistics }\end{array}$ & Italy & $\begin{array}{c}\text { Field } \\
\text { experiment }\end{array}$ & $\begin{array}{l}\text { 1. Transportation has a great } \\
\text { influence on the profitability } \\
\text { of this value chain } \\
\text { 2. Harvesting and storage } \\
\text { methods have to be adjusted } \\
\text { for the benefit of logistics }\end{array}$ \\
\hline $\begin{array}{c}\text { Tzanakakis et al. } \\
\text { (2012) }\end{array}$ & $\begin{array}{l}\text { Giant reed vs. } \\
\text { other non-grass } \\
\text { biomass candidates } \\
\text { for producing } \\
\text { biomass using } \\
\text { wastewater }\end{array}$ & Greece & $\begin{array}{c}\text { Field } \\
\text { experiment }\end{array}$ & $\begin{array}{l}\text { Using pre-treated sewage } \\
\text { effluent for irrigation, Arundo } \\
\text { donax had the second highest } \\
\text { energy production cost but the } \\
\text { highest nutrient-use efficiency } \\
\text { for nitrogen and phosphorus }\end{array}$ \\
\hline $\begin{array}{l}\text { Zema et al. } \\
\text { (2012) }\end{array}$ & $\begin{array}{l}\text { Giant reed vs. } \\
\text { other biomass } \\
\text { candidates for } \\
\text { producing biomass } \\
\text { using wastewater }\end{array}$ & Italy & $\begin{array}{c}\text { Field } \\
\text { experiment }\end{array}$ & $\begin{array}{l}\text { 1. Using effluents of an urban } \\
\text { wastewater increases the yield } \\
\text { of biomass production } \\
\text { 2. Giant reed had the highest } \\
\text { energy yield per unit }\end{array}$ \\
\hline $\begin{array}{l}\text { Seshadri et al. } \\
\qquad(2016)\end{array}$ & $\begin{array}{l}\text { Biomass } \\
\text { production on } \\
\text { landfills }\end{array}$ & Global & $\begin{array}{l}\text { Review of } \\
\text { literature }\end{array}$ & $\begin{array}{l}\text { Giant reed is the most } \\
\text { promising breed with the } \\
\text { highest biomass yield }\end{array}$ \\
\hline
\end{tabular}

Source: Own composition.

\subsubsection{Giant Reed as Biofuel Input}

Arundo donax is an important input of biofuel production, often analysed in several studies (see Table 3). For effective bioethanol production the pre-treatment of the grass biomass is required [4]. This also should be considered once assessing the life-cycle energy balance, as this part is the most energetic intensive part of the production [26]. Against this assumption, Stichnothe, et al. [27] stresses that, currently, the biomass pre-treatment technology available for fermentation is not cost competitive with the traditional sugar-based technologies, therefore further improvements are required. However, chemically and enzymatically pre-treated biomass of Arundo donax consumed by a multistage biorefinery approach was more sustainable (from an energetic point-of-view) than the most common 
feedstock of the lignocellulose biorefinery (e.g., corn stover, switchgrass). Therefore, giant reed is a very good candidate for feeding sustainable biorefineries [28].

Table 3. Summary of biofuel-related studies.

\begin{tabular}{|c|c|c|c|c|}
\hline Study & Topic & Country & Method & Results \\
\hline $\begin{array}{l}\text { Mohapatra et al. } \\
\text { (2017) }\end{array}$ & $\begin{array}{l}\text { Second generation } \\
\text { biofuel production }\end{array}$ & Global & $\begin{array}{l}\text { Review of } \\
\text { literature }\end{array}$ & $\begin{array}{l}\text { For effective bioethanol } \\
\text { production the pre-treatment of } \\
\text { the grass biomass is required. }\end{array}$ \\
\hline $\begin{array}{l}\text { Liguori et al. } \\
\quad(2016)\end{array}$ & $\begin{array}{l}\text { Second generation } \\
\text { biofuel production }\end{array}$ & Global & $\begin{array}{l}\text { Review of } \\
\text { literature }\end{array}$ & $\begin{array}{l}\text { For biofuel production, the } \\
\text { biomass of giant reed requires } \\
\text { pre-treatment which is the most } \\
\text { energetic intensive part of the } \\
\text { production }\end{array}$ \\
\hline $\begin{array}{l}\text { Stichnothe et al. } \\
\text { (2016) }\end{array}$ & $\begin{array}{l}\text { Biomass pretreatment } \\
\text { for fermentation }\end{array}$ & Global & $\begin{array}{l}\text { Theoretical } \\
\text { modelling }\end{array}$ & $\begin{array}{l}\text { Currently the biomass } \\
\text { pre-treatment technology } \\
\text { available for fermentation of giant } \\
\text { reed is not cost competitive }\end{array}$ \\
\hline $\begin{array}{l}\text { Villegas et al. } \\
\text { (2018) }\end{array}$ & $\begin{array}{l}\text { Pre-treatment of } \\
\text { Arundo donax for } \\
\text { biorefineries }\end{array}$ & Italy & Mixed & $\begin{array}{l}\text { Chemically and enzymatically } \\
\text { pre-treated biomass of Arundo } \\
\text { donax consumed by a multistage } \\
\text { biorefinery approach was more } \\
\text { sustainable than the most } \\
\text { common feedstock of the } \\
\text { lignocellulose biorefinery }\end{array}$ \\
\hline $\begin{array}{l}\text { Accardi et al. } \\
\text { (2015) }\end{array}$ & $\begin{array}{l}\text { Second generation } \\
\text { bioethanol production }\end{array}$ & Italy & $\begin{array}{l}\text { Theoretical } \\
\text { modelling }\end{array}$ & $\begin{array}{l}\text { 1. Giant reed is one of the most } \\
\text { promising biomass production } \\
\text { candidates } \\
\text { 2. Giant reed's moisture content } \\
\text { and the holocellulosic-lignin ratio } \\
\text { is in favour of bioethanol } \\
\text { production }\end{array}$ \\
\hline $\begin{array}{l}\text { Sgroiet al. } \\
\text { (2015a) }\end{array}$ & Biogas prodcution & Italy & $\begin{array}{l}\text { Theoretical } \\
\text { modelling }\end{array}$ & $\begin{array}{l}\text { Under Mediterranean } \\
\text { circumstances giant reed is a } \\
\text { promising solution for feeding } \\
\text { biogas plants. }\end{array}$ \\
\hline $\begin{array}{l}\text { Sgroi et al. } \\
\quad(2015 b)\end{array}$ & Biogas prodcution & Italy & $\begin{array}{l}\text { Theoretical } \\
\text { modelling }\end{array}$ & $\begin{array}{l}\text { In profitability terms, plant size of } \\
300 \mathrm{~kW} \text { is the most beneficial for } \\
\text { producing bioenergy from } \\
\text { Arundo donax }\end{array}$ \\
\hline $\begin{array}{l}\text { Fengmin and } \\
\text { Mingquan } \\
\text { (2011) }\end{array}$ & $\begin{array}{l}\text { Effects of binder } \\
\text { content and biomass } \\
\text { content on properties } \\
\text { of biomass briquetting }\end{array}$ & China & $\begin{array}{l}\text { Field } \\
\text { experiment }\end{array}$ & $\begin{array}{l}\text { 1. Giant reed-based briquette has } \\
\text { better calorific value than the } \\
\text { reed based } \\
2 \text {. A mixture of } 45 \% \text { giant reed } \\
\text { together with } 55 \% \text { coal has the } \\
\text { best calorific value }\end{array}$ \\
\hline $\begin{array}{l}\text { Gong et al. } \\
\text { (2013) }\end{array}$ & $\begin{array}{l}\text { Biomass briquetting for } \\
\text { combustion purposes }\end{array}$ & China & $\begin{array}{c}\text { Field } \\
\text { experiment }\end{array}$ & $\begin{array}{l}\text { Mixing giant reed and coal in } \\
\text { briquette can result in } 25 \% \text { cost } \\
\text { reduction and additional } \\
\text { environmental benefits }\end{array}$ \\
\hline $\begin{array}{l}\text { Lesur-Dumoulin et } \\
\text { (2018) }\end{array}$ & ${ }^{\mathrm{tal}}$ Biofuel production & France & $\begin{array}{l}\text { Theoretical } \\
\text { modelling }\end{array}$ & $\begin{array}{l}\text { Combining perennial and/or } \\
\text { annual energy crops with annual } \\
\text { arable crops might end up with } \\
\text { best solution in biofuel production }\end{array}$ \\
\hline $\begin{array}{l}\text { Pantaleo et al. } \\
\text { (2013) }\end{array}$ & $\begin{array}{l}\text { Producing bioenergy } \\
\text { from manure and } \\
\text { energy crops }\end{array}$ & Italy & $\begin{array}{l}\text { Theoretical } \\
\text { modelling }\end{array}$ & $\begin{array}{l}\text { 1. For bioenergy potential, only } \\
\text { manure feedstock is more } \\
\text { profitable than the integration } \\
\text { with energy crops } \\
\text { 2. Giant reed has significant } \\
\text { establishment costs that is } \\
\text { balanced with the relatively low } \\
\text { maintenance costs }\end{array}$ \\
\hline
\end{tabular}


The moisture content and the holocellulosic-lignin ratio of this plant is also in favour of bioethanol production [29]. In their parallel studies the authors also stressed that among biomass crops-under Mediterranean circumstances-giant reed is a promising solution for feeding biogas plants. They also found that in profitability terms, a plant size of $300 \mathrm{~kW}$ is the most beneficial due to the Italian regulations and subsidy system $[30,31]$.

Briquetting biomass is also a solution in order to gain valuable combustible solid biofuels. In a field experiment in China, Fengmin and Mingquan [32] compared the characteristics of giant reed and reed-based briquettes, both mixed with sieved coal together in various composition. They found that $45 \%$ of giant reed share results in the best calorific value. Using this mixed briquettes can result in $25 \%$ cost reduction compared to using solely coal, not mentioning the additional environmental benefits [33]. Moreover, combining perennial and/or annual energy crops with annual arable crops might end up with best solution as the environmental and food/feed producing angles could be optimized in terms of a regional overview, based on cropping system prototypes of Eastern France [34].

Pantaleo, et al. [35] investigated the bioenergy potential of cattle manure and found that the option of only manure feedstock is more profitable than the integration with energy crops. The advantage of low production costs and input requirements for giant reed is balanced by the disadvantages of high establishment costs and the long-term (at least 8-10 years) deployment of the land.

\subsubsection{Food vs. Fuel}

It should be also noted that first-generation biofuel production (e.g., converting sugar or starch into bioethanol) is often criticized in the food versus fuel debate. However, producing energy crops instead of food crops using marginal lands have increased the rationale of lignocellulosic biomass (for a summary, see Table 4).

Table 4. Summary of studies on food vs. fuel studies.

\begin{tabular}{|c|c|c|c|c|}
\hline Study & Topic & Country & Method & Results \\
\hline $\begin{array}{l}\text { Paschalidou et al. } \\
\qquad \text { (2016) }\end{array}$ & $\begin{array}{l}\text { Food vs. fuel } \\
\text { dilemma }\end{array}$ & Greece & $\begin{array}{l}\text { Theoretical } \\
\text { modelling }\end{array}$ & $\begin{array}{l}\text { Giant reed is one of the non-edible } \\
\text { energy crops that are most suitable } \\
\text { for Mediterranean circumstances }\end{array}$ \\
\hline $\begin{array}{l}\text { Popp et al. } \\
\quad(2016)\end{array}$ & $\begin{array}{l}\text { Biofuels and their } \\
\text { co-products as } \\
\text { livestock feed }\end{array}$ & Global & $\begin{array}{l}\text { Review of } \\
\text { literature }\end{array}$ & $\begin{array}{l}\text { Giant reed seems to offer a viable } \\
\text { solution, but the high biomass } \\
\text { potential also accompanies an } \\
\text { invasiveness hazard that should } \\
\text { be treated properly }\end{array}$ \\
\hline $\begin{array}{l}\text { Testa et al. } \\
\quad(2016)\end{array}$ & $\begin{array}{l}\text { Profitability of } \\
\text { Arundo donax } \\
\text { production vs. } \\
\text { conventional crops }\end{array}$ & Italy & Mixed & $\begin{array}{l}\text { 1. Gross margin of production } \\
\text { giant reed for biomass is higher } \\
\text { than for silage } \\
\text { 2. Gross margin of giant reed } \\
\text { production exceeds the } \\
\text { production of conventional crops } \\
\text { (wine grape, melon and tomato) }\end{array}$ \\
\hline
\end{tabular}

Source: Own composition.

The dilemma of producing energy crops for biofuel or for food was in the focus of the Greek study of Paschalidou, et al. [36]. Using a SWOT analysis methodology for evaluation of bioenergy production they also considered giant reed as a candidate for perennial feedstock of biomass production. They found that giant reed is one of the non-edible energy crops that are most suitable for Mediterranean circumstances.

Biofuels and their co-products as livestock feed was the topic of the comprehensives study of Popp, Harangi-Rakos, Gabnai, Balogh, Antal and Bai [1]. They compared conventional and advanced biofuels in terms of their bioenergy potential and contribution to the animal feed supply. The global biofuel industry (both bioethanol and biodiesel) contributes with more than 50 million metric tonnes 
to the feed market, buffering the negative effects of biomass production on global food security. Giant reed, as a dedicated lignocelluloses energy crop which can be produced on marginalized lands, seems to offer a viable solution, but the high biomass potential is also accompanied by an invasiveness hazard that should be treated properly.

A remarkable study of Testa, et al. [37] provides a comparison of giant reed and traditional crop production in Southern Europe. They found that the per hectare annual gross margin was the highest for $A$. donax for biomass production (647 EUR), exceeding $A$. donax for silage purposes (617 EUR), and all the conventional crops like wine grape, melon and tomato $(478,310$ and 280 EUR, respectively). This highlights the potential threat of producing energy crops instead of the conventional varieties.

\subsection{Agronomy}

Our sample contains 18 studies written on the agronomy of giant reed. The first part of these studies analysed yields of giant reed compared to other biomass in a multi-location long-term environment (see Table 5). Alexopoulou, et al. [38], for instance, investigated the long-term yields (11-22 years) of giant reed, switchgrass and Miscanthus grown in northern and southern Greece and Italy. Their results suggested that giant reed yields outperformed switchgrass in a northern Italian environment, and the yield variability of giant reed was also lower. Moreover, switchgrass yields turned out to be $30 \%$ higher in northern regions compared to the south, while Miscanthus showed intermediate production compared to the other two types.

Bonfante, et al. [39] also analysed the yields of giant reed in marginal areas of Italy under climate change as an opportunity to improve farmer's incomes. They found woodchip production to be the most profitable option for farmers, though this option had a gross margin $50 \%$ lower than ordinary high input maize cultivation. Cappelli, et al. [40] also investigated replacement opportunities of corn with giant reed in Italy by running a simulation model. They found giant reed a suitable option for this conversion as biomass production was expected to increase by $20 \%$ in 2020 and $30 \%$ in 2050. Caffrey, et al. [41] also ran a profitability analysis in their model analysing cropland conversion potentials to biomass feedstocks. Their results show that switchgrass was found to be the most profitable ecotype compared to giant reed, Miscanthus and sorghum.

Monti, Zegada-Lizarazu, Zanetti, Casler and Sparks [5] also analysed the yields problem from another angle- they searched for the optimal nitrogen supply of Miscanthus, giant reed and switchgrass, and concluded that the current literature did not provide a sufficiently well-defined picture about the real needs of $\mathrm{N}$ fertilization of these plants. They did, however, find maximized yields were reached with about $100-120 \mathrm{~kg} \mathrm{~N} / \mathrm{ha}^{-1}$ in giant reed and switchgrass.

Another part of the studies in the agronomy field concentrated on harvesting of giant reed (see Table 6). Bentini and Martelli [42], for instance, economically and technologically evaluated a giant reed harvesting system, called the biotriturator, in northern Italy. Results showed that the system represented an effective harvesting solution for not very large areas and was therefore suitable for the Italian environment where average farm sizes were slightly over seven hectares. The same conclusion was drawn by Bentini and Martelli [43], suggesting that this system could also be used effectively for harvesting two other ecotypes, switchgrass and sorghum. Martelli, et al. [44] also analysed harvesting and handling characteristics of giant reed and switchgrass, based on the biotriturator, and found that costs of harvesting, handling, in-field storage and delivery to the conversion plant were lower for giant reed for square bales but not for round bales. However, it is also evident that energy crops need special treatment and techniques in terms of storage and harvesting due to their special characteristics outlined in the introduction section. All in all, the authors have assumed the costs of harvesting, handling, in-field storage and delivery to the conversion plant amounted to $€ 43-46 \mathrm{Mg}^{-1}$ dry for round bales and $€ 35-43 \mathrm{Mg}^{-1}$ for square bales of switchgrass and giant reed for delivery distances of less than $20 \mathrm{~km}$. Romero-Munar, et al. [45] also dealt with a similar topic and analysed how nursery preconditioning of giant reed determined harvest in the first two years. The authors found that small cell preconditioning resulted in smaller sizes in field compared to large cells. As a conclusion, the authors found that better 
nursery conditions resulted in healthier giant reed plants that produced more biomass during the first and second years of cultivation.

Table 5. Summary of studies on yield analysis of giant reed.

\begin{tabular}{|c|c|c|c|c|}
\hline Study & Topic & Country & Method & Results \\
\hline $\begin{array}{l}\text { Alexopoulou et al. } \\
\text { (2015) }\end{array}$ & $\begin{array}{l}\text { Long term yield } \\
\text { comparisons }\end{array}$ & Greece, Italy & Field trials & $\begin{array}{l}\text { 1. Giant reed outperformed } \\
\text { switchgrass in yields under } \\
\text { northern Italy environment } \\
\text { 2. Compared with switchgrass } \\
\text { and Miscanthus, giant reed also } \\
\text { showed lower yield variability } \\
\text { over time and across locations }\end{array}$ \\
\hline $\begin{array}{c}\text { Bonfante et al. } \\
\text { (2017) }\end{array}$ & $\begin{array}{l}\text { Economic potential } \\
\text { of giant reed } \\
\text { production under } \\
\text { climate change }\end{array}$ & Italy & $\begin{array}{l}\text { Simulation } \\
\text { model }\end{array}$ & $\begin{array}{l}\text { 1. Giant reed is profitable and } \\
\text { climate-smart in marginal areas } \\
2 \text {. Woodchip production found to } \\
\text { be the most profitable option for } \\
\text { farmers, though yielding a gross } \\
\text { margin } 50 \% \text { lower than ordinary } \\
\text { high input maize cultivation }\end{array}$ \\
\hline $\begin{array}{l}\text { Cappelli et al. } \\
\text { (2015) }\end{array}$ & $\begin{array}{l}\text { Climate change } \\
\text { impact on giant } \\
\text { reed productivity }\end{array}$ & Italy & $\begin{array}{l}\text { Simulation } \\
\text { model }\end{array}$ & $\begin{array}{l}\text { Giant reed is a suitable option for } \\
\text { local production in terms of } \\
\text { biomass production }\end{array}$ \\
\hline Caffrey et al. (2016) & $\begin{array}{c}\text { potentials in } \\
\text { cropland } \\
\text { conversion to } \\
\text { biomass feedstocks }\end{array}$ & USA & $\begin{array}{l}\text { Economic } \\
\text { modelling }\end{array}$ & $\begin{array}{l}\text { Switchgrass was found to be the } \\
\text { most profitable compared to giant } \\
\text { reed, miscanthus and sorghum }\end{array}$ \\
\hline Monti et al. (2019) & $\begin{array}{l}\text { Optimal nitrogen } \\
\text { supply of } \\
\text { switchgrass, } \\
\text { Miscanthus and } \\
\text { giant reed }\end{array}$ & Global & $\begin{array}{l}\text { Review of } \\
\text { literature }\end{array}$ & $\begin{array}{l}\text { 1. Current literature does not } \\
\text { provide a sufficiently well-defined } \\
\text { picture about the real needs of } \mathrm{N} \\
\text { fertilization of Miscanthus, giant } \\
\text { reed and switchgrass. } \\
\text { 2. Maximized yields are reached } \\
\text { with about } 100-120 \mathrm{~kg} N / \mathrm{ha}^{-1} \text { in } \\
\text { giant reed and switchgrass }\end{array}$ \\
\hline
\end{tabular}

Source: Own composition.

Table 6. Summary of studies on harvest of giant reed.

\begin{tabular}{|c|c|c|c|c|}
\hline Study & Topic & Country & Method & Results \\
\hline $\begin{array}{c}\text { Bentini and } \\
\text { Martelli (2013a) }\end{array}$ & $\begin{array}{l}\text { Economic and } \\
\text { technical analysis of a } \\
\text { harvesting machine, } \\
\text { biotriturator }\end{array}$ & Italy & Field experiment & $\begin{array}{l}\text { The system represents an } \\
\text { effective solution for not very } \\
\text { large areas and is therefore } \\
\text { suitable for the Italian } \\
\text { environment where average } \\
\text { farm sizes are slightly over } \\
\text { seven hectares }\end{array}$ \\
\hline $\begin{array}{c}\text { Bentini and } \\
\text { Martelli (2013b) }\end{array}$ & $\begin{array}{c}\text { Economic and } \\
\text { technical analysis of a } \\
\text { harvesting machine, } \\
\text { biotriturator }\end{array}$ & Italy & Field experiment & $\begin{array}{l}\text { The system represents an } \\
\text { effective solution for not very } \\
\text { large areas and small } \\
\text { farm sizes }\end{array}$ \\
\hline $\begin{array}{l}\text { Martelli et al. } \\
\text { (2015) }\end{array}$ & $\begin{array}{l}\text { Harvest and handling } \\
\text { costs evaluation of } \\
\text { giant reed and } \\
\text { switchgrass }\end{array}$ & Italy & Field experiment & $\begin{array}{l}\text { Costs of harvesting, handling, } \\
\text { in-field storage and delivery to } \\
\text { the conversion plant were } \\
\text { lower for giant reed for square } \\
\text { bales but not for round bales }\end{array}$ \\
\hline $\begin{array}{l}\text { Romero et al. } \\
\qquad(2018)\end{array}$ & $\begin{array}{c}\text { Effects of } \\
\text { preconditioning on } \\
\text { giant reed harvest }\end{array}$ & Spain & Field experiment & $\begin{array}{l}\text { 1. Small cell preconditioning } \\
\text { resulted in smaller sizes in } \\
\text { field compared to large cells. } \\
\text { 2. Better nursery conditions } \\
\text { resulted in healthier giant reed } \\
\text { plants that produced more } \\
\text { biomass during the first and } \\
\text { second years of cultivation }\end{array}$ \\
\hline
\end{tabular}


Several studies were dedicated to the economic and environmental assessment of giant reed inside agronomy literature (see Table 7). Fazio and Barbanti [46] investigated the energy and economic potentials in fifteen annual and perennial species, including giant reed, produced under temperate and tropical areas. In general, they found that the complementary use of crop residues enhanced net energy and energy efficiency, but net profit decreased because of higher costs. Giant reed was found to be the best lignocellulosic crop in the standard scenario. The authors call for a precise evaluation of different species in terms of economic and energy trade-offs.

Hou, et al. [47] did similar research by assessing the economic and ecologic characteristics of four lignocellulosic herbaceous plants (switchgrass, silver reed, giant reed and hybrid Pennisetum) produced in contaminated lands in China. Although all ecotypes were found to have enormous ecological values, hybrid Pennisetum was treated as optimal in ecological value on contaminated lands, while giant reed in economic value.

Fernando, Barbosa, Costa, Papazoglou and Prasad [2] made an excellent review on the environmental, economic and socioeconomic aspects of giant reed, Miscanthus and switchgrass produced on Italian marginal lands. Perennials were found to be more environmentally friendly than annual crops as input requirements are lower and permanence period is longer. However, the authors called for specific attention when environmental impacts are measured as they also found some negative effects (e.g., acidifying emissions, irrigation-related problems, etc.). Economic impacts were also dependent on exact yield and end-use options, while in socioeconomic terms, perennials were found to have positive impacts on job creation and the rural economy.

Lychnaras and Schneider [48] made a multi-farm economic analysis of perennial crops in Greece including giant reed, Miscanthus, switchgrass and cardoon by using microeconomic data from 52 farms. Their results suggest that switchgrass is the most preferable option, while giant reed is the least preferable one (due to its high specific machinery costs). In general, the authors also find that perennial crop production is just an economic option is small farms.

Mehmood, et al. [49] made a detailed overview on biomass production potentials on marginal lands for nine species, including giant reed, and concluded that this crop was suitable for production in the Mediterranean region and had impressive bioenergy feedstock indices. Nassi O Di Nasso, et al. [50] also reviewed existing literature written on economic and environmental aspects of giant reed production in Italy. The authors concluded that giant reed had high production levels, relatively low nutrient requirements, a positive energy balance together with the lowest GHG emissions and the lowest cost per ton of dry biomass or per unit of energy.

Ascenso, et al. [51] assessed multiple biomass feedstock in the optimisation of power and fuel supply chains for sustainable mobility by using a linear programming framework. In their study, first- and second-generation bioethanol and bioelectricity supply chains were assessed considering corn, stover, giant reed, Miscanthus, poplar and wood residues as possible biomass feedstock. Results suggest that a mix of corn-based first generation biorefineries and giant reed-fed power plants give the best technological option. Moreover, Miscanthus, poplar and wood residues were never considered by the solver as a feasible alternative to giant reed or stover for both economic and environmental optimisations.

Accardi, Russo, Lauri, Pietrangeli, Di Palma, Pierucci and Klemes [29] economically evaluated a simplified process for the production of second-generation bioethanol from giant reed by using a simulation software. Their results suggest that giant reed production for biofuel has high economic potential, which may create a potential competitor for oil and other fossil fuels.

Pindozzi, et al. [52] analysed land use changes related to energy crops in hilly Italian areas and found that perennial crop production in these areas would be favourable in all economic dimensions. In the Campania region, giant reed production above 750 metres would yield about $12.6 \mathrm{t} / \mathrm{ha}$ and would massively decrease soil erosion (10 million of tons of $\mathrm{CO}_{2}$ would be saved per year). 
Table 7. Summary of studies on economic and environmental assessment of giant reed.

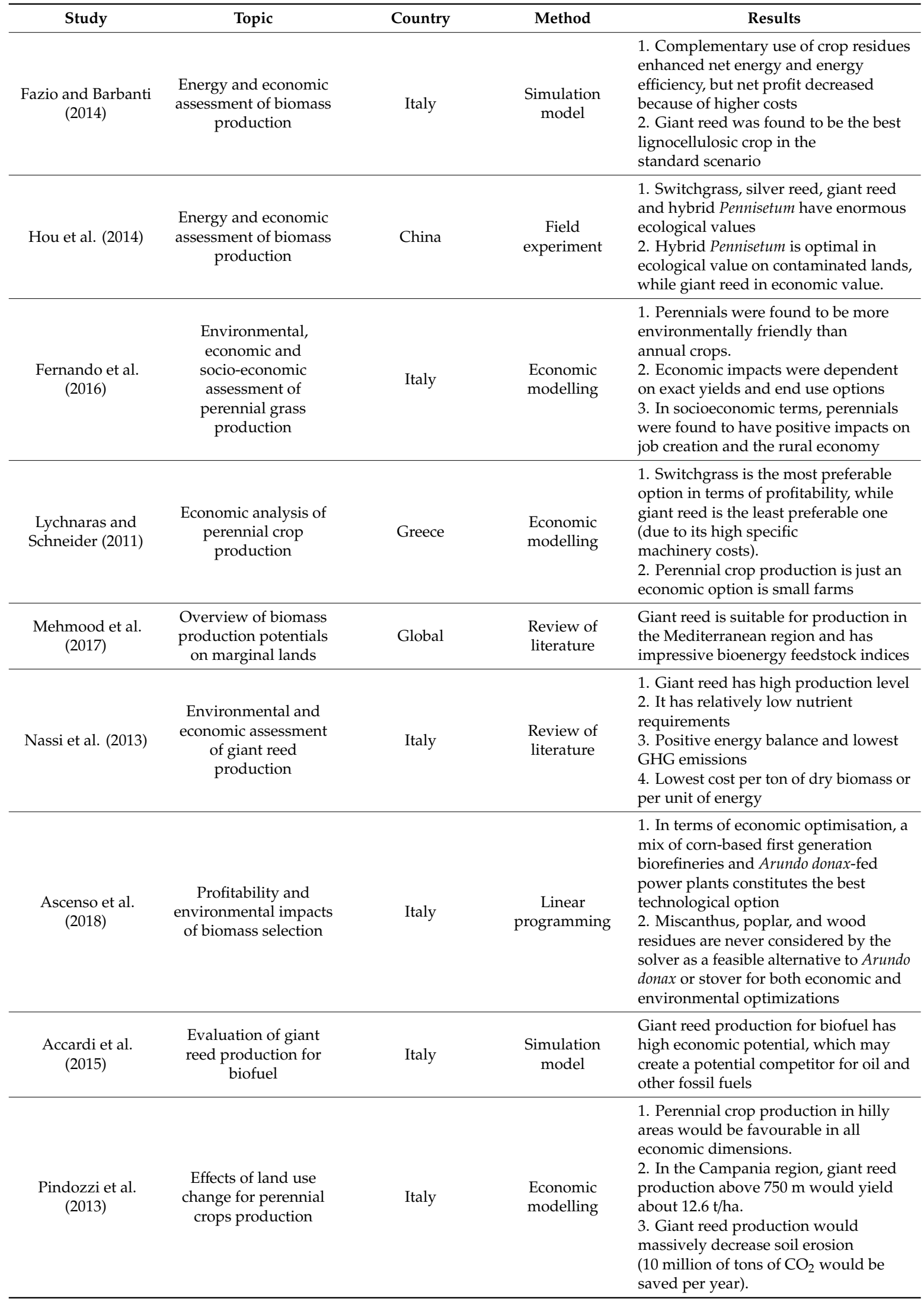


In summary, studies written on the agronomy of giant reed consisted of three topics: Yield, harvest and economic, as well as environmental impact assessment. In general, results differ by location and the method used, but most studies showed that giant reed could be an economic and environmentally wise option in small scale marginal areas in the Mediterranean region.

\subsection{Invasiveness}

Our sample contains eight studies written on the invasiveness of giant reed (see Table 8). Albers, et al. [53] analysed the role of restoration and key ecological invasion mechanisms in optimal spatial-dynamic management of invasive species, including giant reed. By using a bioeconomic modelling approach, their results suggest that more aggressive invasive species and more invasion-susceptible ecosystems require greater investment in habitat restoration despite its relative expense.

Table 8. Summary of studies on invasiveness of giant reed.

\begin{tabular}{|c|c|c|c|c|}
\hline Study & Topic & Country & Method & Results \\
\hline Albers et al. (2018) & $\begin{array}{l}\text { Invasive species } \\
\text { and habitat } \\
\text { management }\end{array}$ & Global & $\begin{array}{l}\text { Bioeconomic } \\
\text { modelling }\end{array}$ & $\begin{array}{l}\text { More aggressive invasive species and } \\
\text { more invasion-susceptible ecosystems } \\
\text { require greater investment in habitat } \\
\text { restoration despite its relative expense }\end{array}$ \\
\hline $\begin{array}{c}\text { Barney and } \\
\text { DiTomaso (2008) }\end{array}$ & $\begin{array}{c}\text { Invasive } \\
\text { characteristics of } \\
\text { non-native species }\end{array}$ & USA & $\begin{array}{l}\text { Weed Risk } \\
\text { Assessment }\end{array}$ & $\begin{array}{l}\text { Switchgrass was found to be highly } \\
\text { invasive in California, giant reed in } \\
\text { Florida, while Miscanthus was not } \\
\text { found to be invasive }\end{array}$ \\
\hline $\begin{array}{c}\text { Goolsby et al. } \\
\text { (2016) }\end{array}$ & $\begin{array}{l}\text { Impact of } \\
\text { biological control } \\
\text { on giant reed }\end{array}$ & USA & Field experiment & $\begin{array}{l}\text { Biological control can be an effective } \\
\text { way of managing invasiveness of } \\
\text { giant reed, though it has serious } \\
\text { economic consequences through } \\
\text { decreased yields }\end{array}$ \\
\hline $\begin{array}{l}\text { Seawright et al. } \\
(2009)\end{array}$ & $\begin{array}{l}\text { Economic } \\
\text { implications of } \\
\text { biological control } \\
\text { for giant reed }\end{array}$ & USA & $\begin{array}{l}\text { Economic } \\
\text { modelling }\end{array}$ & $\begin{array}{l}\text { Biological control can be an effective } \\
\text { way of invasiveness management. } \\
\$ 4.38 \text { of benefits for every dollar of } \\
\text { public investment for a biological } \\
\text { control project for giant reed }\end{array}$ \\
\hline $\begin{array}{l}\text { Gordon et al. } \\
\quad(2011)\end{array}$ & $\begin{array}{l}\text { Invasive potential } \\
\text { of twelve biofuel } \\
\text { species }\end{array}$ & USA & Field experiment & $\begin{array}{l}\text { Giant reed has a high probability to } \\
\text { become invasive and its cultivation } \\
\text { should be avoided }\end{array}$ \\
\hline Nkuna et al. (2018) & $\begin{array}{l}\text { Environmental } \\
\text { impacts of selected } \\
\text { alien grasses }\end{array}$ & South Africa & $\begin{array}{l}\text { Generic Impact } \\
\text { Scoring System }\end{array}$ & $\begin{array}{l}\text { After Cortaderia selloana, giant reed } \\
\text { was the second most invasive plant in } \\
\text { South Africa }\end{array}$ \\
\hline $\begin{array}{l}\text { Rumlerova et al. } \\
\qquad(2016)\end{array}$ & $\begin{array}{l}\text { Categorisation of } \\
\text { alien invasive } \\
\text { plants }\end{array}$ & Europe & $\begin{array}{l}\text { Generic Impact } \\
\text { Scoring System }\end{array}$ & $\begin{array}{l}\text { Giant reed is the second most invasive } \\
\text { species after Lantana camara with the } \\
\text { highest environmental impact }\end{array}$ \\
\hline $\begin{array}{l}\text { Richardson and } \\
\text { Blanchard (2011) }\end{array}$ & $\begin{array}{l}\text { Problems with } \\
\text { invasive biofuel } \\
\text { plants }\end{array}$ & Global & Literature Review & $\begin{array}{l}\text { The cultivation of high-risk species } \\
\text { like giant reed should ideally be } \\
\text { avoided. } \\
\text { When used, biological control or other } \\
\text { mitigation measures, such as the } \\
\text { development of sterile plants, could } \\
\text { potentially be applied }\end{array}$ \\
\hline
\end{tabular}

Source: Own composition.

Barney and DiTomaso [54] analysed the invasive characteristics of switchgrass, giant reed and Miscanthus in the United States. Switchgrass was found to be highly invasive in California, giant reed in Florida, while Miscanthus was not found to be invasive. The authors propose a screening procedure to provide reasonable assurance that bioenergy crops, including giant reed, pose a minimal risk of damaging the local environment. 
Goolsby, et al. [55] also analysed the invasiveness of giant reed in the USA and searched for the impact of a biological control agent on giant reed in Texas. Their results suggest that by using biological control, yields of giant reed decreased on average by $22 \%$, though this control also resulted in the saving of 4.4 million dollars of per year in agricultural water. Seawright, et al. [56] also analysed the invasive potentials of giant reed in the Rio Grande Basin and showed $\$ 4.38$ of benefits for every dollar of public investment for a biological control project for giant reed. For the economic impact analyses, economic output is $\$ 22,000$, value-added is $\$ 11,000$, and no employment is supported by the water savings from giant reed. Additionally, the per-unit cost of water saved was estimated to $\$ 44.08$.

Gordon, et al. [57] were also assessing the invasive potential of twelve species, including giant reed, in Florida. Their results suggest that giant reed has a high probability to become invasive and its cultivation should be avoided.

Nkuna, et al. [58] analysed environmental and socio-economic impacts of 58 selected alien grass species in South Africa by applying the Generic Impact Scoring System method. They found that these species caused a wide range of negative impacts across most habitats. After Cortaderia selloana, giant reed was the second most invasive plant, according to the results. Rumlerová, et al. [59] used the same method and scored environmental and socioeconomic impacts of 128 invasive alien plants in Europe. According to their results, giant reed was the second most invasive species after Lantana camara with the highest environmental impact. Richardson and Blanchard [60] also stresses that cultivation of high-risk species like giant reed should ideally be avoided or strong and strict biological control has to be used.

\subsection{Phytoremediation/Waste Management}

Six articles from our sample was written on the phytoremediation potential of giant reed. Cervelli, et al. [61] investigated bioremediation of polluted areas and analysed poplar and giant reed as possible solutions. Results suggest that both crops may serve as tools for bioremediation of contaminated soils and their use increase the value of ecosystem services. Similar results were reached by Cervelli, et al. [62], including more scenarios and land use change options. Results here show that combining ecological assessment with land use change scenarios provide useful input for future regional development and conservation.

Cristaldi, et al. [63] analysed phytoremediation of contaminated soils by heavy metals and reviewed the different techniques available. Amongst others, giant reed was found to improve soil biological fertility in assisted phytoremediation of an industrial polluted soil. Fernando, Barbosa, Costa, Papazoglou and Prasad [2] reached similar conclusions when analysing phytoremediation potentials of giant reed by reviewing the associated literature. Their conclusion was that giant reed was a perfect candidate to improve the quality of water-polluted bodies, being able to remove various ions and heavy metals. In contaminated soils, giant reed was also found to improve many soil properties, being able to remove heavy metals and some types of radionuclides, among other inorganic compounds. Nsanganwimana, et al. [64] also provided a review on how giant reed can phytomanage water and soils contaminated by trace elements and it was found that the crop had high potentials to improve soil and water quality and thereby increasing land availability.

Chiarawatchai, et al. [65] were in search for identifying alternative plants to improve resource recovery efficiency in subsurface-flow constructed wetlands. Based on the investigation of 45 species, 13 were found suitable for the purpose above, including giant reed in warm areas of Southern Europe and subtropical areas in South Africa.

The remaining articles were concentrating on giant reed and waste management (see Table 9). Jin, et al. [66] reviewed papers written on the processing of plant-derived waste to produce value added products based on the biorefinery concept. Giant reed wastes were found to be one of the potential candidates to be used in food, chemical and biofuel production. Pelegrín, et al. [67] evaluated various co-composting scenarios based on the use of giant reed as bulking agent for co-composting of sewage sludge and agri-food sludge. Their results confirmed the viability of the composting process as 
a method for the stabilization of organic wastes. Salzman, et al. [68] explored the economic viability of using constructed wetlands to manage wastewater in the dairy industry and giant reed was found as a potential crop meeting the requirements.

Table 9. Summary of studies on phytoremediation/waste management of giant reed.

\begin{tabular}{|c|c|c|c|c|}
\hline Study & Topic & Country & Method & Results \\
\hline Cervelli et al. (2016) & $\begin{array}{l}\text { Bioremediation of } \\
\text { contaminated areas }\end{array}$ & Italy & $\begin{array}{l}\text { Economic } \\
\text { modelling }\end{array}$ & $\begin{array}{l}\text { Poplar and giant reed can serve } \\
\text { as tools for bioremediation of } \\
\text { contaminated soils and their use } \\
\text { increase the value of } \\
\text { ecosystem services }\end{array}$ \\
\hline Cervelli et al. (2017) & $\begin{array}{l}\text { Land use change and } \\
\text { ecosystems services }\end{array}$ & Italy & $\begin{array}{l}\text { Economic } \\
\text { modelling }\end{array}$ & $\begin{array}{l}\text { Combining ecological } \\
\text { assessment with land use } \\
\text { change scenarios provide useful } \\
\text { input for future regional } \\
\text { development and conservation }\end{array}$ \\
\hline Cristaldi et al. (2017) & $\begin{array}{l}\text { Phytoremediation of } \\
\text { contaminated soils by heavy } \\
\text { metals }\end{array}$ & Global & $\begin{array}{l}\text { Literature } \\
\text { review }\end{array}$ & $\begin{array}{l}\text { Giant reed was found to } \\
\text { improve soil biological fertility } \\
\text { in assisted phytoremediation of } \\
\text { an industrial polluted soil }\end{array}$ \\
\hline Fernando et al. (2016) & $\begin{array}{l}\text { Phytoremediation potential } \\
\text { of giant reed }\end{array}$ & Global & $\begin{array}{l}\text { Literature } \\
\text { review }\end{array}$ & $\begin{array}{l}\text { Giant reed was a perfect } \\
\text { candidate to improve the quality } \\
\text { of water-polluted bodies and } \\
\text { contaminated soils }\end{array}$ \\
\hline $\begin{array}{l}\text { Nsanganwimana et al. } \\
\text { (2014) }\end{array}$ & $\begin{array}{l}\text { Phytoremediation potential } \\
\text { of giant reed }\end{array}$ & Global & $\begin{array}{l}\text { Literature } \\
\text { review }\end{array}$ & $\begin{array}{l}\text { Giant reed has high potentials to } \\
\text { improve soil and water quality } \\
\text { and thereby increasing land } \\
\text { availability }\end{array}$ \\
\hline $\begin{array}{l}\text { Chiarawatchai et al. } \\
\text { (2008) }\end{array}$ & $\begin{array}{l}\text { Improvement of resource } \\
\text { recovery efficiency in } \\
\text { constructed wetlands }\end{array}$ & Global & $\begin{array}{l}\text { Literature } \\
\text { review }\end{array}$ & $\begin{array}{l}\text { Giant reed can improve resource } \\
\text { recovery efficiency in } \\
\text { constructed wetlands in warm } \\
\text { areas of Southern Europe and } \\
\text { subtropical areas in South Africa }\end{array}$ \\
\hline Jin et al. (2018) & $\begin{array}{l}\text { Production from } \\
\text { plant-derived wastes }\end{array}$ & Global & $\begin{array}{l}\text { Literature } \\
\text { review }\end{array}$ & $\begin{array}{l}\text { Giant reed waste is among } \\
\text { potential candidates to be used } \\
\text { in food, chemical and biofuel } \\
\text { production }\end{array}$ \\
\hline Pelegrín et al. (2018) & $\begin{array}{l}\text { Composting of giant reed } \\
\text { with sewage and agri-food } \\
\text { sludge }\end{array}$ & Spain & $\begin{array}{c}\text { Field } \\
\text { experiment }\end{array}$ & $\begin{array}{l}\text { Giant reed is viable to be part of } \\
\text { a composting process for the } \\
\text { stabilization of organic wastes }\end{array}$ \\
\hline Salzman et al. (2017) & $\begin{array}{l}\text { Economic viability of using } \\
\text { constructed wetlands to } \\
\text { manage wastewater in the } \\
\text { dairy industry }\end{array}$ & Australia & $\begin{array}{l}\text { Field } \\
\text { experiment }\end{array}$ & $\begin{array}{l}\text { Giant reed has high potentials in } \\
\text { wastewater management }\end{array}$ \\
\hline
\end{tabular}

\section{Conclusions}

This paper systematically analysed the literature written on the economics of $A$. donax. We have identified four main categories (bioenergy, agronomy, invasiveness and phytoremediation) under which 68 articles were written. Most papers were focusing on Italy and on the Mediterranean region.

As to bioenergy, every second paper was written on this topic. Papers generally highlighted the many different uses of $A$. donax as a biomass available for bioenergy and biofuel production, pelleting and briquetting. It has relatively high energy balance ( $4654.4 \mathrm{GJ} / \mathrm{ha})$. Regarding agronomy aspects, giant reed was found to have relatively high yields (approx. $16 \mathrm{t} / \mathrm{ha}$ ) due to its climate tolerant and resistant characteristics. Most studies found that the species has a high investment ( $€ 1200 / \mathrm{ha}$, on average) but low maintenance cost (estimated 15-20 years of production), so cultivation was advisable just in the long run. The plant also shows high potential of phytoremediation of contaminated soils. 
However, a certain section of the literature, mainly based on US experience, shows that giant reed should be produced with care due to its invasiveness hazard.

As a general conclusion, A. donax was found to have high economic potential for biomass production in marginal as well as disadvantageous lands operated by small farmers in the Mediterranean region.

Author Contributions: Conceptualization, A.J. and Á.T.; Methodology, A.J. and Á.T.; Software, A.J. and Á.T.; Validation, A.J. and Á.T.; Formal Analysis, A.J. and Á.T.; Resources, A.J. and Á.T.; Data Curation, A.J. and Á.T.; Writing-Original Draft Preparation, A.J. and Á.T.; Writing-Review \& Editing, A.J. and Á.T.; Visualization, A.J. and Á.T.; Supervision, A.J. and Á.T.; Project Administration, A.J. and Á.T.; Funding Acquisition, A.J. and Á.T.

Funding: This research was funded by the National Research, Development and Innovation Office of Hungary, grant number GINOP 2.2.1-15-2017-00042 (The Genetic Utilization of the Plants in the Pannon Region).

Conflicts of Interest: The authors declare no conflict of interest.

\section{References}

1. Popp, J.; Harangi-Rakos, M.; Gabnai, Z.; Balogh, P.; Antal, G.; Bai, A. Biofuels and Their Co-Products as Livestock Feed: Global Economic and Environmental Implications. Molecules 2016, 21, 285. [CrossRef] [PubMed]

2. Fernando, A.L.; Barbosa, B.; Costa, J.; Papazoglou, E.G.; Prasad, M.N.V. Chapter 4-Giant Reed (Arundo donax L.): A Multipurpose Crop Bridging Phytoremediation with Sustainable Bioeconomy. Bioremed. Bioecon. 2016, 77-95. [CrossRef]

3. Nocentini, A.; Field, J.; Monti, A.; Paustian, K. Biofuel production and soil GHG emissions after land-use change to switchgrass and giant reed in the U.S. Southeast. Food Energy Secur. 2018, 7. [CrossRef]

4. Mohapatra, S.; Mishra, C.; Behera, S.S.; Thatoi, H. Application of pretreatment, fermentation and molecular techniques for enhancing bioethanol production from grass biomass-A review. Renew. Sustain. Energy Rev. 2017, 78, 1007-1032. [CrossRef]

5. Monti, A.; Zegada-Lizarazu, W.; Zanetti, F.; Casler, M.; Sparks, D.L. Nitrogen Fertilization Management of Switchgrass, Miscanthus and Giant Reed: A Review. Adv. Agron. 2019, 153, 87-119. [CrossRef]

6. Prochnow, A.; Heiermann, M.; Plöchl, M.; Amon, T.; Hobbs, P.J. Bioenergy from permanent grassland-A review: 2. Combustion. Bioresour. Technol. 2009, 100, 4945-4954. [CrossRef] [PubMed]

7. Venturi, P.; Venturi, G. Analysis of energy comparison for crops in European agricultural systems. Biomass Bioenergy 2003, 25, 235-255. [CrossRef]

8. Gupta, V.K.; Potumarthi, R.; O’Donovan, A.; Kubicek, C.P.; Sharma, G.D.; Tuohy, M.G.; Gupta, V.K.; Tuohy, M.G.; Kubicek, C.P.; Saddler, J.; et al. Chapter 2-Bioenergy Research: An Overview on Technological Developments and Bioresources. Bioenergy Res. Adv. Appl. 2014, 23-47. [CrossRef]

9. Nackley, L.L.; Quinn, L.D.; Matlaga, D.P.; Barney, J.N. Good Intentions vs Good Ideas: Evaluating Bioenergy Projects that Utilize Invasive Plant Feedstocks; Cabi Publishing-C a B Int: Wallingford, UK, 2015; Volume 5, pp. 134-153.

10. Soldatos, P. Economic Aspects of Bioenergy Production from Perennial Grasses in Marginal Lands of South Europe. Bioenergy Res. 2015, 8, 1562-1573. [CrossRef]

11. Alderucci, V.; Giordano, A.; Iovino, A.; Giordano, N.; Phillips, V.D. Potential biomass resources of Sicily for electric-power generation. Appl. Energy 1993, 45, 219-240. [CrossRef]

12. Chinnici, G.; D'Amico, M.; Rizzo, M.; Pecorino, B. Analysis of biomass availability for energy use in Sicily. Renew. Sustain. Energy Rev. 2015, 52, 1025-1030. [CrossRef]

13. Milovanovic, J.; Drazic, G.; Ikanovic, J.; Jurekova, Z.; Rajkovic, S. Sustainable production of biomass through miscanthus giganteus plantation development. Ann. Fac. Eng. Hunedoara 2012, 10, 79-82.

14. Singh, M.P.; Erickson, J.E.; Sollenberger, L.E.; Woodard, K.R.; Vendramini, J.M.B.; Gilbert, R.A. Mineral composition and removal of six perennial grasses grown for bioenergy. Agron. J. 2015, 107, 466-474. [CrossRef]

15. Panoutsou, C. Socio-economic impacts of energy crops for heat generation in Northern Greece. Energy Policy 2007, 35, 6046-6059. [CrossRef] 
16. Pulighe, G.; Bonati, G.; Colangeli, M.; Morese, M.M.; Traverso, L.; Lupia, F.; Khawaja, C.; Janssen, R.; Fava, F. Ongoing and emerging issues for sustainable bioenergy production on marginal lands in the Mediterranean regions. Renew. Sustain. Energy Rev. 2019, 103, 58-70. [CrossRef]

17. Chiaramonti, D.; Grimm, H.-P.; Bassam, N.E.; Cendagorta, M. Energy crops and bioenergy for rescuing deserting coastal area by desalination: feasibility study. Bioresour. Technol. 2000, 72, 131-146. [CrossRef]

18. Pulighe, G.; Bonati, G.; Fabiani, S.; Barsali, T.; Lupia, F.; Vanino, S.; Nino, P.; Arca, P.; Roggero, P.P. Assessment of the Agronomic Feasibility of Bioenergy Crop Cultivation on Marginal and Polluted Land: A GIS-Based Suitability Study from the Sulcis Area, Italy. Energies 2016, 9, 895. [CrossRef]

19. Sulas, L.; Franca, A.; Sanna, F.; Re, G.A.; Melis, R.; Porqueddu, C. Biomass characteristics in Mediterranean populations of Piptatherum miliaceum-A native perennial grass species for bioenergy. Ind. Crop. Prod. 2015, 75, 76-84. [CrossRef]

20. Rodias, E.; Berruto, R.; Bochtis, D.; Busato, P.; Sopegno, A. A computational tool for comparative energy cost analysis of multiple-crop production systems. Energies 2017, 10, 831. [CrossRef]

21. Pari, L.; Assirelli, A.; Acampora, A.; Del Giudice, A.; Santangelo, E. A new prototype for increasing the particle size of chopped Arundo donax (L.). Biomass Bioenergy 2015, 74, 288-295. [CrossRef]

22. Pari, L.; Curt, M.D.; Sánchez, J.; Santangelo, E. Economic and energy analysis of different systems for giant reed (Arundo donax L.) harvesting in Italy and Spain. Ind. Crop. Prod. 2016, 84, 176-188. [CrossRef]

23. Tzanakakis, V.A.; Chatzakis, M.K.; Angelakis, A.N. Energetic environmental and economic assessment of three tree species and one herbaceous crop irrigated with primary treated sewage effluent. Biomass Bioenergy 2012, 47, 115-124. [CrossRef]

24. Zema, D.A.; Bombino, G.; Andiloro, S.; Zimbone, S.M. Irrigation of energy crops with urban wastewater: Effects on biomass yields, soils and heating values. Agric. Water Manag. 2012, 115, 55-65. [CrossRef]

25. Seshadri, B.; Bolan, N.S.; Thangarajan, R.; Jena, U.; Das, K.C.; Wang, H.; Naidu, R.; Prasad, M.N.V. Chapter 5-Biomass Energy from Revegetation of Landfill Sites*. Bioremediat. Bioecon. 2016, 99-109. [CrossRef]

26. Liguori, R.; Ventorino, V.; Pepe, O.; Faraco, V. Bioreactors for lignocellulose conversion into fermentable sugars for production of high added value products. Appl. Microbiol. Biotechnol. 2016, 100, 597-611. [CrossRef]

27. Stichnothe, H.; Meier, D.; de Bari, I.; Lamers, P.; Searcy, E.; Hess, J.R.; Stichnothe, H. Chapter 3-Biorefineries: Industry Status and Economics. Dev. Glob. Bioecon. 2016, 41-67. [CrossRef]

28. Villegas Calvo, M.; Colombo, B.; Corno, L.; Eisele, G.; Cosentino, C.; Papa, G.; Scaglia, B.; Pilu, R.; Simmons, B.; Adani, F. Bioconversion of Giant Cane for Integrated Production of Biohydrogen, Carboxylic Acids, and Polyhydroxyalkanoates (PHAs) in a Multistage Biorefinery Approach. Acs Sustain. Chem. Eng. 2018, 6, 15361-15373. [CrossRef]

29. Accardi, D.S.; Russo, P.; Lauri, R.; Pietrangeli, B.; Di Palma, L.; Pierucci, S.; Klemes, J.J. From soil remediation to biofuel: Process simulation of bioethanol production from Arundo donax. Chem. Eng. Trans. 2015, 43, 2167-2172. [CrossRef]

30. Sgroi, F.; Di Trapani, A.M.; Foderà, M.; Testa, R.; Tudisca, S. Economic performance of biogas plants using giant reed silage biomass feedstock. Ecol. Eng. 2015, 81, 481-487. [CrossRef]

31. Sgroi, F.; Foderà, M.; Trapani, A.M.D.; Tudisca, S.; Testa, R. Economic evaluation of biogas plant size utilizing giant reed. Renew. Sustain. Energy Rev. 2015, 49, 403-409. [CrossRef]

32. Fengmin, L.; Mingquan, Z. Technological Parameters of Biomass Briquetting of Macrophytes in Nansi Lake. Energy Procedia 2011, 5, 2449-2454. [CrossRef]

33. Gong, L.; Wang, Z.Y.; Zhang, M.Q.; Li, F.M.; Tang, X.F.; Wu, Y.; Yao, Y.; Zhang, Z.Z. Properties and Benefits of Biomass Briquetting of Macrophytes in Nansi Lake. Mater. Sci. Forum 2013, 743-744, 797-801. [CrossRef]

34. Lesur-Dumoulin, C.; Laurent, A.; Reau, R.; Guichard, L.; Ballot, R.; Jeuffroy, M.H.; Loyce, C. Co-design and ex ante assessment of cropping system prototypes including energy crops in Eastern France. Biomass Bioenergy 2018, 116, 205-215. [CrossRef]

35. Pantaleo, A.; Gennaro, B.D.; Shah, N. Assessment of optimal size of anaerobic co-digestion plants: An application to cattle farms in the province of Bari (Italy). Renew. Sustain. Energy Rev. 2013, 20, 57-70. [CrossRef]

36. Paschalidou, A.; Tsatiris, M.; Kitikidou, K. Energy crops for biofuel production or for food?-SWOT analysis (case study: Greece). Renew. Energy 2016, 93, 636-647. [CrossRef] 
37. Testa, R.; Foderà, M.; Di Trapani, A.M.; Tudisca, S.; Sgroi, F. Giant reed as energy crop for Southern Italy: An economic feasibility study. Renew. Sustain. Energy Rev. 2016, 58, 558-564. [CrossRef]

38. Alexopoulou, E.; Zanetti, F.; Scordia, D.; Zegada-lizarazu, W.; Christou, M.; Testa, G.; Cosentino, S.L.; Monti, A. Long-Term Yields of Switchgrass, Giant Reed, and Miscanthus in the Mediterranean Basin. Bioenergy Res. 2015, 8, 1492-1499. [CrossRef]

39. Bonfante, A.; Impagliazzo, A.; Fiorentino, N.; Langella, G.; Mori, M.; Fagnano, M. Supporting local farming communities and crop production resilience to climate change through giant reed (Arundo donax L.) cultivation: An Italian case study. Sci. Total Environ. 2017, 601, 603-613. [CrossRef]

40. Cappelli, G.; Yamaç, S.S.; Stella, T.; Francone, C.; Paleari, L.; Negri, M.; Confalonieri, R. Are advantages from the partial replacement of corn with second-generation energy crops undermined by climate change? A case study for giant reed in northern Italy. Biomass Bioenergy 2015, 80, 85-93. [CrossRef]

41. Caffrey, K.R.; Chinn, M.S.; Veal, M.W. Biomass supply chain management in North Carolina (part 1): predictive model for cropland conversion to biomass feedstocks. Aims Energy 2016, 4, 256-279. [CrossRef]

42. Bentini, M.; Martelli, R. Prototype for the harvesting of cultivated herbaceous energy crops, an economic and technical evaluation. Biomass Bioenergy 2013, 57, 229-237. [CrossRef]

43. Bentini, M.; Martelli, R. Giant reed (Arundo donax L.) harvesting system, an economic and technical evaluation. J. Agric. Eng. 2013, 44, 607-609. [CrossRef]

44. Martelli, R.; Bentini, M.; Monti, A. Harvest storage and handling of round and square bales of giant reed and switchgrass: An economic and technical evaluation. Biomass Bioenergy 2015, 83, 551-558. [CrossRef]

45. Romero-Munar, A.; Tauler, M.; Gulías, J.; Baraza, E. Nursery preconditioning of Arundo donax L. plantlets determines biomass harvest in the first two years. Ind. Crop. Prod. 2018, 119, 33-40. [CrossRef]

46. Fazio, S.; Barbanti, L. Energy and economic assessments of bio-energy systems based on annual and perennial crops for temperate and tropical areas. Renew. Energy 2014, 69, 233-241. [CrossRef]

47. Hou, X.C.; Fan, X.F.; Zhu, Y.; Wu, J.Y.; Zhao, C.Q.; Zheng, S.S. Ecological-economic values of Lignocellulosic herbaceous plant on contaminated land. Adv. Mater. Res. 2014, 852, 757-763. [CrossRef]

48. Lychnaras, V.; Schneider, U.A. Multi-farm economic analysis of perennial energy crops in Central Greece, taking into account the CAP reform. Biomass Bioenergy 2011, 35, 700-715. [CrossRef]

49. Mehmood, M.A.; Ibrahim, M.; Rashid, U.; Nawaz, M.; Ali, S.; Hussain, A.; Gull, M. Biomass production for bioenergy using marginal lands. Sustain. Prod. Consum. 2017, 9, 3-21. [CrossRef]

50. Nassi O Di Nasso, N.; Roncucci, N.; Bonari, E. Giant reed (Arundo donax L.) as energy crop in Central Italy: A review. Ital. J. Agron. 2013, 8, 10-17.

51. Ascenso, L.; d'Amore, F.; Carvalho, A.; Bezzo, F. Assessing multiple biomass-feedstock in the optimization of power and fuel supply chains for sustainable mobility. Chem. Eng. Res. Des. 2018, 131, 127-143. [CrossRef]

52. Pindozzi, S.; Faugno, S.; Cervelli, E.; Capolupo, A.; Sannino, M.; Boccia, L. Consequence of land use changes into energy crops in Campania region. J. Agric. Eng. 2013, 44, 467-471. [CrossRef]

53. Albers, H.J.; Hall, K.M.; Lee, K.D.; Taleghan, M.A.; Dietterich, T.G. The Role of Restoration and Key Ecological Invasion Mechanisms in Optimal Spatial-Dynamic Management of Invasive Species. Ecol. Econ. 2018, 151, 44-54. [CrossRef]

54. Barney, J.N.; DiTomaso, J.M. Nonnative Species and Bioenergy: Are We Cultivating the Next Invader? Bioscience 2008, 58, 64-70. [CrossRef]

55. Goolsby, J.A.; Moran, P.J.; Racelis, A.E.; Summy, K.R.; Jimenez, M.M.; Lacewell, R.D.; Perez de Leon, A.; Kirk, A.A. Impact of the biological control agent Tetramesa romana (Hymenoptera: Eurytomidae) on Arundo donax (Poaceae: Arundinoideae) along the Rio Grande River in Texas. Biocontrol Sci. Technol. 2016, 26, 47-60. [CrossRef]

56. Seawright, E.K.; Rister, M.E.; Lacewell, R.D.; McCorkle, D.A.; Sturdivant, A.W.; Yang, C.; Goolsby, J.A. Economic implications for the biological control of arundo donax: Rio Grande Basin. Southw. Entomol. 2009, 34, 377-394. [CrossRef]

57. Gordon, D.R.; Tancig, K.J.; Onderdonk, D.A.; Gantz, C.A. Assessing the invasive potential of biofuel species proposed for Florida and the United States using the Australian Weed Risk Assessment. Biomass Bioenergy 2011, 35, 74-79. [CrossRef]

58. Nkuna, K.V.; Visser, V.; Wilson, J.R.U.; Kumschick, S. Global environmental and socio-economic impacts of selected alien grasses as a basis for ranking threats to South Africa. NeoBiota 2018, 41, 19-65. [CrossRef] 
59. Rumlerová, Z.; Vilà, M.; Pergl, J.; Nentwig, W.; Pysek, P. Scoring environmental and socioeconomic impacts of alien plants invasive in Europe. Biol. Invasions 2016, 18, 3697-3711. [CrossRef]

60. Richardson, D.M.; Blanchard, R. Learning from our mistakes: minimizing problems with invasive biofuel plants. Curr. Opin. Environ. Sustain. 2011, 3, 36-42. [CrossRef]

61. Cervelli, E.; Pindozzi, S.; Capolupo, A.; Okello, C.; Rigillo, M.; Boccia, L. Ecosystem services and bioremediation of polluted areas. Ecol. Eng. 2016, 87, 139-149. [CrossRef]

62. Cervelli, E.; Pindozzi, S.; Sacchi, M.; Capolupo, A.; Cialdea, D.; Rigillo, M.; Boccia, L. Supporting land use change assessment through Ecosystem Services and Wildlife Indexes. Land Use Pol. 2017, 65, 249-265. [CrossRef]

63. Cristaldi, A.; Conti, G.O.; Jho, E.H.; Zuccarello, P.; Grasso, A.; Copat, C.; Ferrante, M. Phytoremediation of contaminated soils by heavy metals and PAHs. A brief review. Environ. Technol. Innov. 2017, 8, 309-326. [CrossRef]

64. Nsanganwimana, F.; Marchand, L.; Douay, F.; Mench, M. Arundo donax L., a Candidate for Phytomanaging Water and Soils Contaminated by Trace Elements and Producing Plant-Based Feedstock. A Review. Int. J. Phytoremediat. 2014, 16, 982. [CrossRef]

65. Chiarawatchai, N.; Heers, M.; Otterpohl, R. Criteria for determining alternative plants to improve the resource recovery efficiency in constructed wetlands. Water Sci. Technol. 2008, 58, 1665-1670. [CrossRef]

66. Jin, Q.; Yang, L.; Poe, N.; Huang, H. Integrated processing of plant-derived waste to produce value-added products based on the biorefinery concept. Trends Food Sci. Technol. 2018, 74, 119-131. [CrossRef]

67. Pelegrín, M.; Sáez-Tovar, J.A.; Andreu-Rodríguez, J.; Pérez-Murcia, M.D.; Martínez-Sabater, E.; Marhuenda-Egea, F.C.; Pérez-Espinosa, A.; Bustamante, M.A.; Agulló, E.; Vico, A.; et al. Composting of the invasive species Arundo donax with sewage and agri-food sludge: Agronomic, economic and environmental aspects. Waste Manag. 2018, 78, 730-740. [CrossRef]

68. Salzman, S.; Scarborough, H.; Allinson, G. Exploring the economic viability of using constructed wetlands to manage waste-water in the dairy industry. Australas. J. Environ. Manag. 2017, 24, 276-288. [CrossRef]

(C) 2019 by the authors. Licensee MDPI, Basel, Switzerland. This article is an open access article distributed under the terms and conditions of the Creative Commons Attribution (CC BY) license (http://creativecommons.org/licenses/by/4.0/). 